\title{
Effects of Foreign Education on Immigrant Earnings
}

\author{
Eric Fong \\ University of Toronto \\ fong@chass.utoronto.ca
}

\author{
Xingshan $\mathrm{Cao}^{1}$ \\ Arthritis Community Research and Evaluation Unit \\ University Health Network, Toronto \\ xs.cao@utoronto.ca
}

\begin{abstract}
This study explores the effects of foreign education on earnings. Previously, most research used indirect estimated information about foreign education, and documented the lower earnings of immigrants who had foreign education in comparison to those who had domestic education. Using direct information obtained from respondents of a recent survey, this research goes beyond the existing studies by suggesting three factors in earning discounts: (1) whether the highest level of education was received overseas, (2) the country where foreign education was received, and (3) name recognition of the foreign university. In addition, our study points out that social networks can reduce the foreign education discount, especially in nonprofessional occupations.
\end{abstract}

Keywords: immigrant earnings, education, social networks

\section{Résumé}

Cette recherche explore les effets de l'éducation acquise à l'étranger sur le niveau des gains. Auparavant, la majorité des enquêtes se basaient sur une estimation indirecte des données sur l'éducation acquise à l'étranger et documentaient les gains moins élevés des immigrants qui avaient reçu leur éducation à l'étranger en comparaison à ceux qui avaient suivi leurs études au pays. En utilisant des données directes recueillies auprès des répondants d'un récent sondage, cette étude va plus loin que les études actuelles en suggérant trois facteurs dans la réduction des gains : 1) est-ce que le plus haut niveau de scolarité a été acquis à l'étranger, 2) dans quel pays l'éducation a-t-elle été reçue, et 3) quel est le niveau de réputation de l'université étrangère. De plus, notre étude indique que les réseaux sociaux peuvent diminuer

1. This research was supported by the Social Sciences and Humanities Research Council of Canada. Correspondence to Eric Fong, Department of Sociology, 725 Spadina Avenue, University of Toronto, Toronto, ON, Canada. M5S 2J4. We appreciate the help of Wenhong Chen to create two variables. 
la réduction des gains causée par l'éducation acquise à l'étranger, particulièrement dans les professions non-diplômées.

Mots clés : gains des immigrants, éducation, réseaux sociaux

\section{Introduction}

It has long been established in social science literature that education strongly affects earnings and varies by immigration status (Aydemir and Skuterud, 2005; Baker and Benjamin, 1995; Borjas, 1982; Ferrer and Riddell, 2002; Lofstrom, 2001). However, this relationship has become more complicated in recent years. With the increasingly interconnected global economy and immigration policies designed to recruit immigrants who are ready to integrate into the labour market, there has been a substantial growth in the migration of skilled workers. Many of these immigrants have received part, or sometimes all, of their education overseas. Drawing from the National Survey of College Graduates and the 2000 census, Zeng and Xie (2004) estimated that more than half the Asian immigrants in the United States had completed their education outside the country. Similarly, studies in Canada, another major immigrant receiving country, have found that about half the immigrants have completed their highest education outside Canada (Li, 2001). Immigrants with foreign education encounter a discount on their earnings in the new country. Zeng and Xie (2004) showed that immigrants in the USA with foreign education earned about $14 \%$ less than those who were American trained. Li (2001) documented that some immigrants in Canada with foreign education earn almost $\$ 10,000$ less than those with Canadian education.

Although previous studies have documented the earning discount of foreign education on immigrants' earnings (Boyd, 2001; Li, 2001; Zeng and Xie, 2004), we know very little about how the foreign education discount operates and how immigrants minimize its effects. Based on recently collected data on immigrants in Toronto, this article advances the understanding of the effects of foreign education in three ways. First, we identify three determinants for earning discounts for foreign education: (1) whether the highest level of education was received overseas, (2) the country where foreign education was received, and (3) name recognition of the foreign university. We believe that this study is the first to compare the effects of different sources of foreign education discounts on earnings. Second, we envisage that institutional characteristics have an important effect on foreign education discounts on earnings. We therefore analyze separately the 
effects of foreign education on earnings in professional and nonprofessional occupations. Finally, we study how immigrants minimize the foreign education discount on earnings. The discussion puts the understanding of foreign education discounts in the context of immigrant adaptation. In particular, we explore how social networks give immigrants some relief from the foreign education discount on earnings. This approach acknowledges that while immigrants' economic integration is under institutional constraints, they attempt to overcome these limitations through various means. The study is based on unique data obtained as direct information about the foreign education experience of immigrants, providing more comprehensive understanding of the effects of foreign education on the earnings of immigrants. As various government agencies, professional groups, and nongovernment organizations (such as Canadian Association for Prior Learning Assessment) are developing procedures and mechanisms to recognize foreign education and credentials, the information provided in this study will be useful for their discussion and planning.

\section{Assimilation, Earnings, and Institutions}

Individual economic behaviours are not only guided by cost and benefit calculation, but are also influenced by the institutional rules where the economic activities occur (Fligstein, 2001; Reitz, 1999). Sociological inquiry has long emphasized the significance of embedded institutional effects on economic behaviour. It can be found in classical sociological work from the time of Durkheim and Weber, and recently has been re-emphasized and advanced (Alba and Nee, 2003; Nee and Ingram, 1998).

Recent studies have applied the institutional approach to explore how institutions affect economic integration of immigrants. According to these studies, as immigrants settle in the new country, competition, or sometimes even conflict, may arise between the immigrant and native-born populations. To minimize possible conflict in the process of immigrant integration, institutions may "regulate" the economic activities of immigrants, which subsequently affects the economic integration process. However, the economic integration of immigrants is not the outcome that reflects the passive accommodation of institutional arrangements. Alba and Nee (2003) argue that immigrants actively use their various forms of socioeconomic resources to maximize outcomes within the existing institutional constraints. Simply put, according to these researchers, assimilation involves two processes. The first process is the way in which institutions regulate, and sometimes intentionally or unintentionally constrain, the economic outcomes of immi- 
grants. The second is the way in which immigrants use their existing socioeconomic resources within institutional constraints to maximize outcomes.

The discount effect of foreign education on earnings can be viewed as an important indicator of how institutions regulate the economic integration of immigrants. As Shibutani and Kwan (1965) argued in their classic, Ethnic Stratification, institutions maintain the existing equilibrium of resource distribution among existing members, and minimize possible competition generated by new members. Thus, the earning discount of foreign education minimizes competition from new members by carefully delineating the boundaries that differentiate resources accumulated before and after immigration (Barth, 1969; DaVanzo and Morrison, 1981). At the same time, social networks are resources that immigrants can draw on to minimize these constraints.

With these theoretical underpinnings, this paper elaborates upon the effects on immigrants' earnings of human capital resources acquired before immigration. Specifically, we compare the sources of the foreign education discount effects on earnings; outline three aspects of foreign education discount that affect earning potential; and discuss possible differences in foreign education discount on earnings between professional and nonprofessional occupations. Finally, we explore how social networks alleviate the foreign education discount effects on earnings.

\section{Foreign Education and Earnings}

The discount effect of foreign education rests on the proposition that human capital is location specific and not easily transferable. As a result, earnings of immigrants who received foreign education are discounted in the labour market (Krupka, 2004). However, the discussion offers does not differentiate effects of various trajectories of foreign education or to specify effects of education obtained from different countries and rankings of schools.

Drawing on economic literature on education and earnings, we extend the study of foreign education effects on earnings by identifying three sources of foreign education discount on earnings of immigrants: whether the highest level of education was received overseas, the country where the foreign education was received, and the name recognition of the foreign university. This distinction is theoretically important as it demonstrates the ways in which foreign education affects earnings. More importantly, it illustrates how institutions constrain the economic outcomes of immigrants (Alba and Nee, 1997; Waldinger, Aldrich, and Ward, 1990). 


\section{Highest Level of Education Received Overseas}

The concept of endowment in education literature explains the earning discount associated with education received overseas. Studies suggest that earnings are affected not only by the time spent by the individual on education, but also by the endowments associated with the education received (Behrman, Rosenzweig, and Taubman, 1996). Education endowment refers to the "inputs" or characteristics associated with different levels or types of education that affect earning potential (Bratsberg and Terrell, 2002). These resources include interaction skills, expectations, or information about the labour market that are embedded in the learning process (Card and Krueger 1992a; 1992b). They are helpful during the job search, which in turn can translate into higher earnings. In a very thorough evaluation of endowment effects, Heckman and colleagues (1996) show that endowment affects different education groups in different ways (Heckman, Layne-Farra, and Todd, 1996:596). In particular, education endowment has a stronger effect on higher skill occupations.

To translate these findings to earning discounts associated with education received overseas, we expect that individuals who receive foreign education are exposed to location-specific endowments that may not transfer easily or equally to another country. In contrast, the endowments associated with education in the host country are more readily translated in the local labour market. Subsequently, the earnings of immigrants who received education overseas are discounted. Among various education trajectories of immigrants, the effect is especially strong for those who received their highest level of education in foreign countries. This group of immigrants has minimal exposure to the operations and expectations of the labour market in the new country.

\section{Name Recognition of Foreign University and Region where Foreign Education was Received}

The earning discount of foreign education varies according to the country where the education was received and name recognition of the foreign institution. Drawing from the screening theories in education literature, labour economists (Belman and Heywood, 1991; Park, 1999) propose the importance of the "sheepskin effects" of education on earnings. They argue that education levels serve as indicators of certain levels of productivity. Employers recruit workers according to these indicators and the market rewards these indicators accordingly. Therefore, most studies of the sheepskin effects expect that individuals who graduated with a diploma earn more than 
those who studied for the same number of years without obtaining a diploma. Drawing from the Current Population Survey, Jaeger and Page (1996) show that this effect is particularly strong for postsecondary education.

These arguments have direct and significant implications for understanding the earning discount of foreign education, especially for those who have completed university. Employers usually know little about foreign educational systems. There are similar sheepskin effects associated with the locations of foreign universities and their name recognition. Local employers may be reluctant to hire immigrants who graduated from countries where the university system is less familiar, or from less known foreign universities. These immigrants will experience earnings discounts in the host country.

\section{Professionals and Earnings}

To understand earnings attainments, it is important to differentiate between professional and nonprofessional occupations. Professional occupations are usually associated with greater prestige, stable career path, and, most importantly, higher income (Barringer, Takeuchi, and Xenos, 1990; Leicht and Fennell, 2001). Because professional occupations usually involve credentials, certification, and regulation by professional associations, there is pressure to develop similar evaluation practices and structures (Dimaggio and Powell, 1983). This strong institutional isomorphism becomes a powerful force to ensure similar economic returns for those in professional occupations, including immigrants with foreign education. Professional occupations typically have clear evaluation criteria for foreign education based on credentials and certifications. In addition, the government, working with various professional groups, has made headway in setting up tests and clear guidelines for evaluating foreign-trained professionals. In nonprofessional occupations, there are considerable variations in the evaluation criteria (Kennedy, 2003).

Research documents that immigrants are underrepresented in the professional occupations, such engineering and science (Tang, 1993). While immigrants are certainly constrained by lack of human capital resources and limited social networks, studies show that discrimination is also a contributing factor (Boyd, 2001). Nevertheless, among those immigrants who secure professional positions, we expect the foreign education discount effect to be minimal, as there is strong institutional isomorphism among professional occupations. 


\section{Social Networks and Earnings}

The focus of our discussion is to disentangle the discount effects of foreign education. However, the discussion is not complete without considering how immigrants use their resources to maximize their outcomes under institutional constraints. Since studies document the significance of social networks for immigrants to minimize their disadvantages, it is particularly important to address how social networks alleviate the discount effects of foreign education (Sanders, Nee, and Sernau, 2002).

Within the context of ethnic economy, studies on the use of social networks by immigrants in their economic adaptation process argue that, because of coethnic trust and solidarity, employers are more willing to hire coethnic workers who may not have the necessary qualifications (Sanders, 2002; Waldinger, 1999). This practice provides immigrants with favorable earnings returns on their qualifications, including their educational credentials (Light and Gold, 2000; Sanders and Nee, 1987). However, some studies suggest that immigrants experience lower earnings working in coethnic businesses.

Studies exploring the effects of social networks on earnings beyond the context of ethnic economy (Sanders, Nee, and Sernau, 2002) suggest that social networks, and ethnic networks in particular, most likely lead to low-paying jobs for immigrants outside the ethnic economy. Fernandez and Fernandez-Mateo (2006) point out that such outcomes reflect the "wrong networks" used by job seekers, because members in the mobilized networks lack credibility or reputation among employers (Smith, 2005). Thus, the "quality" of social networks determines the jobs with different earning potential. Findings by Ooka and Wellman (2006) in their Toronto-based study echo this argument about social network quality. They show that the social networks of ethnic groups with greater resources are more likely to lead to desirable jobs. One key implication of these studies is that the discount effects of foreign education on earnings will not always increase, but can be reduced when immigrants have more extensive social networks (Lin, 2001).

In short, drawing from the literature, our discussion differentiates three sources of earning discounts associated with foreign education. The earning discount of foreign education associated with those who received their highest education overseas; with those who graduated from world regions with which local employers are not familiar; or from universities with less recognizable names. However, we also note that these various sources of foreign education discount are lower for people who are in professional occupations and have more extensive social networks. 


\section{Data and Methods}

The data for this research were drawn from a telephone survey conducted in 2005 in Toronto, Ontario, Canada, part of a larger study investigating immigrant adaptation in the new economy. The study included 1,539 respondents aged 18 years or older. Of these respondents, we oversampled Chinese and Asian Indians and weighted them to reflect their proportion in the general Toronto population.

In this study, we weighted Chinese and Asian Indians to reflect their proportion in the general Toronto population. We are particularly interested in the effects of foreign education on earnings. The dependent variable is self-reported personal employment income, in intervals ranging from below $\$ 20,000$ to over $\$ 200,000$. The median income interval is between $\$ 20,000$ and $\$ 39,999$.

One of the key independent variables is the highest level of foreign education received. Highest education refers to "no university completion," "completion of university," and "completion of graduate school." We grouped respondents into four different foreign education trajectories: Canadian-born who received their education in Canada, immigrants who received their highest education in foreign countries, immigrants who received some foreign education but completed their highest education in Canada, and immigrants who received all their education in Canada. We expect that immigrants who receive their highest education in foreign countries receive earnings discounts. Canadian-born respondents who received their education in Canada are included for the purpose of comparison with immigrants.

A categorical variable measures the region or the country where foreign education was received. The variable indicates the place of education by major regions: "Asia," "US, UK, or Western Europe," "Eastern Europe," "Canada," and "other regions." Some regions were grouped into one category because of a limited number of cases. Caution is needed when interpreting the results, as there may be different effects of the country where foreign education was received among local Canadian employers because employers may have varying levels of knowledge of foreign countries.

A dummy variable is used to represent whether the foreign institution is a high-ranking university. We used the ranking of foreign universities published by Shanghai Jiaotong University in 2005 (http://ed.sjtu.edu.cn/ ranking.htm), in which the top 500 universities in the world were selected by region. Their ranking was based on the publication impact and citation of faculty and alumni, and the size of institution. We selected this ranking because it is based on objective criteria, rather than other rankings based on 
interview or evaluation by scholars, which could be affected by the choice of candidates interviewed or evaluated. We define a university as high ranking if it is on the list. These are major universities in various regions and although their names are generally familiar to the Canadian public, they are not necessarily familiar to all Canadian employers. Therefore, our interpretation of the results is cautious.

We expect that immigrants who were educated in foreign countries, especially Asian countries, will encounter significant earning discounts, because employers in Canada are less familiar with foreign universities and systems. The earning discount is particularly significant for those educated at less known universities.

Our analysis also takes two other factors into consideration. First, we ran separate analyses for professional and nonprofessional occupations to differentiate possible institutional differences in the discount effect of foreign education on earnings. Our classification is based on the National Occupational Classification Matrix, which provides an overview of the entire occupational classification structure based on skill levels and skill types. The matrix was developed by Human Resources and Skills Development Canada (http://www23.hrdc-drhc.gc.ca/2001/e/generic/matrix.pdf). Selfreported occupations in our sample that matched any occupations at a management level and at skill level A or B of the NOC Matrix were classified as professional occupations.

Second, our model considers the extent of the respondents' social networks. This is measured by two variables derived from the position generator, a survey instrument commonly used to capture the extent of a respondent's social networks (Lin, 2001; Lin and Dumin, 1986). The first variable, "upper reachability," focuses on the potential resources that an individual's networks can obtain. It is the highest occupational prestige score associated with the occupations to which the respondent has access. The second variable, "extensity," is the range between the highest and the lowest occupation to which the respondent has access, thus showing the extent of the individual's social networks. The occupational prestige score is based on the findings of Ganzeboom and Treiman (1996). Descriptive statistics of the independent variables are reported in Appendix 1.

In our statistical model, we control for a number of factors for possible effects on earnings: level of highest education, age, gender, language ability, being a visible minority, being employed in a professional occupation, weeks of work, and hours of work.

Interval regression is used in this analysis. Since the dependent variable, individual income, has the lowest category left-censored and the highest category right-censored, and the remaining categories are interval-censored, 
it could not be analyzed in a straightforward manner by OLS regression or by an ordered logit (probit) model. Interval regression is a statistical method that specifically models this type of censored variable. Unlike ordered logit regression, the predicted value is not about the probability of certain categories of the dependent variable occurring, nor is it required to meet the proportionality assumption. In our analysis using interval regression, we recoded the dependent variable into thousands and transformed it into a natural logged scale. We recognize that the interval regression is sensitive to outlying intervals. Therefore, as mentioned above, we have been very careful in our coding of the locations and rankings of the foreign universities to ensure that there are no categories with only a few cases. ${ }^{2}$

\section{Results}

Table 1 shows the earnings distribution of respondents by their trajectories of foreign education in professional and nonprofessional occupations. The first panel has the earnings of all respondents. The results show the earning disparity of immigrants who received their highest education in foreign countries. These immigrants have distinctly lower income. However, not all immigrants with foreign education have lower earnings. Immigrants who have some foreign education but completed their highest education in Canada do considerably well. About $18 \%$ of this group, the highest percentage among all immigrants with foreign education trajectories, earns $\$ 80,000$ or more. This percentage of high earners is greater than in the Canadianborn population. At the same time, this group has the lowest percentage of individuals earning $\$ 20,000$ or less. Most likely, they were foreign students who completed university in Canada and decided to stay. Their Canadian university training and foreign background may be attractive to the local labour market in Toronto with its multiethnic population.

The earnings of immigrants with no foreign education, who are most likely the 1.5 generation who arrived in Canada when they were young, have similar earnings to people born in Canada. About $14 \%$ of this group earns $\$ 80,000$ and over, while the rate for the Canadian-born population is $12 \%$. Similarly, $38 \%$ of this group earns $\$ 20,000$ or less, compared to $39 \%$ of the Canadian-born population.

2. We compared OLS results with the interval regression results to find out whether the interval regression results were considerably different. If this were the case, our interval regression results might have to be interpreted with caution. However, the findings do not show substantial differences of direction in the relationships between independent and dependent variables. 
Table 1: Earning Distribution by Foreign Education Experience

\begin{tabular}{|c|c|c|c|c|}
\hline & $\begin{array}{l}\text { Below } \\
\$ 20,000\end{array}$ & $\begin{array}{l}\$ 20,000- \\
\$ 39,999\end{array}$ & $\begin{array}{l}\$ 40,000- \\
\$ 79,999\end{array}$ & $\begin{array}{l}\$ 80,000 \\
\text { and above }\end{array}$ \\
\hline \multicolumn{5}{|l|}{ Total } \\
\hline Canadian-born & 39.42 & 20.51 & 27.88 & 12.18 \\
\hline $\begin{array}{l}\text { Immigrants with some foreign education but } \\
\text { completed highest education in Canada }\end{array}$ & 27.81 & 20.86 & 33.69 & 17.64 \\
\hline $\begin{array}{l}\text { Immigrants completed highest education in } \\
\text { foreign countries }\end{array}$ & 41.65 & 30.31 & 22.06 & 5.98 \\
\hline Immigrants, no foreign education & 38.10 & 26.19 & 21.43 & 14.29 \\
\hline \multicolumn{5}{|l|}{ Professional Occupations } \\
\hline Canadian-born & 19.59 & 14.43 & 46.39 & 19.59 \\
\hline $\begin{array}{l}\text { Immigrants with some foreign education but } \\
\text { completed highest education in Canada }\end{array}$ & 15.15 & 16.67 & 40.91 & 27.27 \\
\hline $\begin{array}{l}\text { Immigrants completed highest education in } \\
\text { foreign countries }\end{array}$ & 16.67 & 26.67 & 43.33 & 13.33 \\
\hline Immigrants, no foreign education & 7.14 & 35.71 & 42.86 & 14.29 \\
\hline \multicolumn{5}{|l|}{ Nonprofessional occupations } \\
\hline Canadian-born & 48.37 & 23.26 & 19.53 & 8.84 \\
\hline $\begin{array}{l}\text { Immigrants with some foreign education but } \\
\text { completed highest education in Canada }\end{array}$ & 34.17 & 23.33 & 30.00 & 12.50 \\
\hline $\begin{array}{l}\text { Immigrants completed highest education in } \\
\text { foreign countries }\end{array}$ & 49.86 & 31.51 & 15.07 & 3.56 \\
\hline Immigrants, no foreign education & 44.29 & 24.29 & 17.14 & 14.29 \\
\hline
\end{tabular}

The second and third panels of the table display the earnings of respondents by separate trajectories of foreign education in professional and nonprofessional occupations. A disparity is observed between professional and nonprofessional respondents. Nonetheless, the earnings disparity among immigrants with different trajectories of foreign education is the same for both professional and nonprofessional respondents.

The earnings disparity reported in Table 1 could be related to other social and demographic factors in addition to the foreign education discount. In the following analyses, we control for various factors to understand the effects of foreign education on immigrant earnings.

\section{Level of Education Received Overseas}

The first set of interval regression analyses reported in Table 2 examines earning discounts among immigrants who received foreign education at different stages of their educational pursuits. We expect that those who received their highest education in foreign countries will experience a significant earning discount. We ran three sets of analysis. The first set includes all respondents. The second and third sets include respondents who work in 
professional and nonprofessional occupations respectively. In each set, we ran two models. The first model includes various trajectories of foreign education received, controlling for the social and demographic backgrounds of respondents. The second model adds additional variables to capture the social networks of respondents. Canadian-born respondents with only Canadian education serve as contrast to immigrants with various trajectories of foreign education.

The results of the first model show that only immigrants who received their highest education in foreign countries experience earning discounts. The results clearly suggest that foreign education does not necessarily lead

Table 2. Interval Regression Estimates of Earnings on Foreign Education Experience and Other Selected Variables

\begin{tabular}{|c|c|c|c|c|c|c|}
\hline & \multicolumn{2}{|c|}{ All } & \multicolumn{2}{|c|}{ Professional } & \multicolumn{2}{|c|}{ Nonprofessional } \\
\hline & Model 1 & Model 2 & Model 1 & Model 2 & Model 1 & Model 2 \\
\hline \multicolumn{7}{|l|}{ Education levels } \\
\hline Graduate school & $0.368^{\star \star \star}$ & $0.345^{\star \star \star}$ & $0.450^{\star \star \star}$ & $0.433^{\star \star *}$ & $0.354^{\star}$ & $0.357^{\star}$ \\
\hline University & $0.317^{\star \star \star}$ & $0.288^{\star \star \star}$ & 0.113 & 0.098 & $0.473^{\star \star \star}$ & $0.437^{\star \star \star}$ \\
\hline College or below & $\mathrm{cc}$ & & & & & \\
\hline \multicolumn{7}{|l|}{$\begin{array}{l}\text { Demographic and } \\
\text { socioeconomic factors }\end{array}$} \\
\hline Age & $0.023^{\star \star \star}$ & $0.022^{\star \star \star}$ & $0.029^{\star \star \star}$ & $0.029^{\star \star \star}$ & $0.022^{\star \star \star}$ & $0.021^{\star \star \star}$ \\
\hline Gender (Females=1) & $-0.395^{\star \star \star}$ & $-0.391^{\star \star \star *}$ & -0.128 & -0.135 & $-0.458^{\star \star \star}$ & $-0.452^{\star * \star}$ \\
\hline Visible minority & $-0.203^{\star \star \star}$ & $-0.192^{\star \star}$ & 0.004 & 0.007 & $-0.223^{\star}$ & $-0.211^{\star \star}$ \\
\hline $\begin{array}{l}\text { Language ability: well and } \\
\text { very well }\end{array}$ & $0.655^{\star \star \star}$ & $0.652^{\star \star \star}$ & 0.289 & 0.299 & $0.576^{\star}$ & $0.527^{\star \star}$ \\
\hline Professional occupations & $0.285^{\star \star \star}$ & $0.289^{\star \star \star}$ & & & & \\
\hline Ln (weeks of work) & 0.004 & 0.003 & 0.075 & 0.067 & -0.030 & -0.039 \\
\hline Ln (hours of work) & $0.103^{*}$ & 0.101 & $0.274^{\star \star}$ & $0.273^{\star \star}$ & 0.128 & 0.136 \\
\hline \multicolumn{7}{|l|}{$\begin{array}{l}\text { Foreign education } \\
\text { experience }\end{array}$} \\
\hline $\begin{array}{l}\text { Immigrants completed highest } \\
\text { education in foreign countries }\end{array}$ & $-0.207^{\star \star}$ & $-0.163^{*}$ & $-0.283^{\star \star}$ & $-0.263^{\star \star}$ & $-0.298^{\star \star}$ & $-0.262^{\star *}$ \\
\hline $\begin{array}{l}\text { Immigrants no foreign } \\
\text { education }\end{array}$ & 0.171 & 0.153 & -0.154 & -0.167 & $0.309^{*}$ & 0.296 \\
\hline $\begin{array}{l}\text { Immigrants with foreign } \\
\text { education and completed } \\
\text { highest education in Canada }\end{array}$ & 0.039 & 0.024 & -0.180 & -0.191 & $0.153^{\star \star}$ & 0.120 \\
\hline Canadian born & $\mathrm{cC}$ & & & & & \\
\hline \multicolumn{7}{|l|}{ Social networks } \\
\hline Upper reachability & & $0.016^{\star \star}$ & & 0.008 & & $0.017^{\star \star}$ \\
\hline Extensity & & $0.004^{\star \star}$ & & 0.001 & & 0.006 \\
\hline Intercept & $1.735^{\star \star \star}$ & $0.483^{\star \star}$ & $1.170^{\star \star}$ & 0.600 & $1.873^{\star \star \star}$ & $0.502^{*}$ \\
\hline Sigma & 0.682 & 0.668 & 0.586 & 0.586 & 0.723 & 0.707 \\
\hline $\mathrm{N}$ & 1245 & 1245 & 349 & 297 & 904 & 770 \\
\hline Log pseudolikelihood & -831.47 & -822.6 & -607.13 & -595.50 & -533.03 & -1142.966 \\
\hline
\end{tabular}


to earning discounts. The second model, shown in Column 2, adds variables to capture the effects of the respondents' social networks. The results strongly suggest that extensive social networks help to reduce the earning discount.

The third and fourth columns relate to respondents working in professional occupations. Even in highly isomorphic occupational structures, the earning discount of individuals who completed their highest education in foreign countries cannot be erased. The effects of social networks on earnings are limited among professional occupations.

The last two columns include only respondents working in nonprofessional occupations. Like their counterparts in professional occupations, immigrants working in nonprofessional occupations who received their highest education in foreign countries experience a significant discount on earnings. However, the results show that, unlike those in professional occupations, completing their highest education in Canada has positive and significant effects on the earnings of those with some foreign education. The last column shows the results when respondents' social networks are included. It indicates that social networks are significant in improving the earnings of respondents working in nonprofessional occupations, and that they considerably reduce the discount on earnings. However, it is possible that the greater number of significant effects associated with nonprofessional occupations are related to the larger sample size. Interpreting these results should be done with caution.

\section{Foreign Universities or Regions with Educational Systems Unfamiliar to Canadian Employers}

So far the results have demonstrated the earning discount for immigrants who received their highest education in foreign countries, whether in professional or nonprofessional occupations. In this section, we explore possible earning discounts associated with foreign universities and regions with education systems unfamiliar to Canadian employers. Subsequent analysis focuses on individuals who have completed university education.

Table 3 presents the effects of the earning discounts associated with whether a foreign university is known to the Canadian public. Only individuals who completed university are included in the analysis. We included a variable to indicate whether the foreign university is ranked among the top 500. The contrast category is university completion in Canada. This category also includes respondents who received foreign education before they completed university in Canada. Our previous analysis has shown that this group, like individuals who received all their education in Canada, enjoys 
higher earnings. Although all the high-ranking universities are generally well known, not all of their names are recognized by local residents and employers. Therefore, we are cautious in our interpretation. The setup of the analysis is similar to that of the previous analysis.

The results of the first model, which includes all respondents, suggest that those who completed foreign university education, whether from highranking or low-ranking universities, experienced the earning discount of foreign education. Thus it would seem that immigrants' earnings are affected not by whether the foreign universities are known by local employers, but rather by the foreign education itself. The second model further includes the social networks of respondents. The results show that social networks, specifically upper reachability, are positively and significantly related to earnings. Social networks help to reduce the earning discount of completing university in a foreign country, if the university is high-ranking. Earning disadvantages remain for individuals who completed university at a low-ranking foreign institution.

\section{Table 3. Interval Regression Estimates of Earnings on Foreign} University Education by Rankings and Other Selected Variables.

\begin{tabular}{|c|c|c|c|c|c|c|}
\hline & \multicolumn{2}{|c|}{ All } & \multicolumn{2}{|c|}{ Professional } & \multicolumn{2}{|c|}{ Nonprofessional } \\
\hline & Model 1 & Model 2 & Model 1 & Model 2 & Model 1 & Model 2 \\
\hline \multicolumn{7}{|l|}{ Foreign university ranking } \\
\hline Foreign university top 500 & $-0.274^{\star}$ & -0.21 & 0.064 & 0.148 & $-0.555^{\star}$ & $-0.515^{\star}$ \\
\hline Foreign university below 500 & $-0.274^{\star \star}$ & $-0.22^{*}$ & -0.027 & 0.007 & $-0.449^{\star \star}$ & $-0.390^{\star \star}$ \\
\hline Canadian university & $\mathrm{cc}$ & $\mathrm{cc}$ & $\mathrm{cc}$ & $\mathrm{cc}$ & $\mathrm{cc}$ & $\mathrm{cc}$ \\
\hline \multicolumn{7}{|l|}{$\begin{array}{l}\text { Demographic and } \\
\text { socioeconomic factors }\end{array}$} \\
\hline Age & $0.021^{\star \star \star}$ & $0.02^{\star \star \star}$ & $0.025^{\star \star \star}$ & $0.024^{\star \star \star}$ & $0.018^{\star \star \star}$ & $0.017^{\star \star}$ \\
\hline Gender (Female=1) & $-0.313^{\star \star \star}$ & $-0.33^{\star \star \star}$ & -0.112 & -0.141 & $-0.411^{\star \star \star}$ & $-0.411^{\star \star \star}$ \\
\hline Visible minority & -0.097 & -0.10 & 0.129 & 0.117 & $-0.306^{\star \star}$ & $-0.289^{\star \star}$ \\
\hline $\begin{array}{l}\text { Language ability, well and very } \\
\text { well }\end{array}$ & $0.630^{\star \star \star}$ & $0.54^{\star \star}$ & $0.610^{\star}$ & 0.551 & $0.606^{\star \star}$ & $0.515^{\star \star}$ \\
\hline $\begin{array}{l}\text { Professional } \\
\text { occupations }\end{array}$ & $0.298^{\star \star \star}$ & $0.30^{\star \star \star}$ & & & & \\
\hline Ln (weeks of work) & -0.034 & -0.04 & $0.160^{\star}$ & 0.145 & -0.170 & $-0.170^{\star}$ \\
\hline Ln (hours of work) & 0.122 & $0.13^{*}$ & 0.388 & $0.400^{*}$ & $0.243^{\star \star}$ & $0.243^{\star \star}$ \\
\hline Canadian born & 0.022 & -0.01 & 0.170 & 0.139 & -0.115 & -0.141 \\
\hline \multicolumn{7}{|l|}{ Social networks } \\
\hline Upper reachability & & $0.02^{\star \star}$ & & 0.009 & & $0.026^{\star \star}$ \\
\hline Extensity & & 0.00 & & 0.007 & & 0.003 \\
\hline Intercept & $2.117^{\star \star \star}$ & 0.76 & 0.150 & -0.626 & $2.603^{\star \star \star}$ & 0.796 \\
\hline Sigma & 0.711 & 0.69 & 0.579 & 0.566 & 0.757 & 0.737 \\
\hline $\mathrm{N}$ & 452 & 452 & 172 & 172 & 280 & 280 \\
\hline Log likelihood & -723.44 & -713.66 & -291.21 & -287.7 & -423.6 & -403.57 \\
\hline
\end{tabular}


The earning discount associated with university ranking is quite different when only respondents who work in professional occupations are considered. The results in the first model show that having completed education in a foreign university, whether in the top 500 or not, is statistically insignificant. In other words, receiving foreign education is not significantly related to earnings even when name recognition is taken into consideration. The insignificant relationship remains when the variables of social networks are included in the analysis. As in the previous analysis, social networks do not play an important role in explaining the earnings of people who work in professional occupations.

For those working in nonprofessional occupations, it is not the ranking of the foreign university, but having received foreign university education that affects immigrants' earnings. Even when social networks are included in the model, the effects of foreign education remain the same.

Table 4. Interval Regression Estimates of Earnings on University Completion from Different Regions and other Selected Variables.

\begin{tabular}{|c|c|c|c|c|c|c|}
\hline & \multicolumn{2}{|c|}{ All } & \multicolumn{2}{|c|}{ Professional } & \multicolumn{2}{|c|}{ Nonprofessional } \\
\hline & Model 1 & Model 2 & Model 1 & Model 2 & Model 1 & Model 2 \\
\hline \multicolumn{7}{|l|}{$\begin{array}{l}\text { Region where university } \\
\text { completed }\end{array}$} \\
\hline Asian & $-0.233^{\star}$ & -0.161 & 0.098 & 0.123 & $-0.467^{\star \star}$ & $-0.361^{*}$ \\
\hline US, UK, Western Europe & $-0.522^{\star \star}$ & $-0.443^{\star}$ & $-0.546^{\star}$ & -0.453 & $-0.531^{\star}$ & $-0.494^{\star}$ \\
\hline Eastern Europe & -0.313 & -0.241 & -0.037 & 0.015 & $-0.478^{*}$ & -0.403 \\
\hline Others & -0.249 & -0.215 & 0.084 & 0.078 & -0.312 & -0.251 \\
\hline Canada & $\mathrm{CC}$ & $\mathrm{CC}$ & $\mathrm{cc}$ & $\mathrm{CC}$ & $\mathrm{CC}$ & $\mathrm{CC}$ \\
\hline \multicolumn{7}{|l|}{$\begin{array}{l}\text { Demographic and } \\
\text { socioeconomic factors }\end{array}$} \\
\hline Age & $0.021^{\star \star \star}$ & $0.020^{\star \star \star}$ & $0.027^{\star \star \star}$ & $0.026^{\star \star \star}$ & $0.019^{\star \star \star}$ & $0.017^{\star \star}$ \\
\hline Gender (female=1) & $-0.320^{\star \star \star}$ & $-0.336^{\star \star \star}$ & -0.145 & $-0.167^{\star}$ & $-0.400^{\star \star \star}$ & $-0.406^{\star \star \star}$ \\
\hline Visible minority & -0.115 & -0.117 & 0.128 & 0.125 & $-0.293^{\star}$ & $-0.296^{\star}$ \\
\hline $\begin{array}{l}\text { Language ability: well and very } \\
\text { well }\end{array}$ & $0.622^{\star \star \star}$ & $0.547^{\star \star}$ & $0.655^{\star}$ & 0.603 & $0.537^{*}$ & $0.483^{\star}$ \\
\hline $\begin{array}{l}\text { Professional } \\
\text { occupations }\end{array}$ & $0.304^{\star \star \star}$ & $0.314^{\star \star \star}$ & & & & \\
\hline Ln (weeks of work) & -0.026 & -0.032 & $0.177^{\star}$ & $0.165^{\star}$ & -0.161 & -0.158 \\
\hline Ln (hours of work) & $0.113^{*}$ & $0.116^{\star}$ & 0.360 & 0.366 & $0.241^{\star}$ & $0.234^{\star \star}$ \\
\hline Canadian born & 0.014 & -0.010 & 0.189 & 0.166 & -0.107 & -0.119 \\
\hline \multicolumn{7}{|l|}{ Social networks } \\
\hline Upper reachability & & $0.019^{*}$ & & 0.009 & & $0.026^{\star \star}$ \\
\hline Extensity & & 0.005 & & 0.005 & & 0.002 \\
\hline Intercept & $2.127^{\star \star \star}$ & 0.767 & 0.106 & -0.561 & $2.623^{\star \star \star}$ & 0.809 \\
\hline Sigma & 0.708 & 0.693 & 0.559 & 0.551 & 0.760 & 0.743 \\
\hline $\mathrm{N}$ & 452 & 452 & 172 & 172 & 280 & 280 \\
\hline Log likelihood & -722.01 & -712.76 & -286.15 & -283.93 & -410.79 & -404.86 \\
\hline
\end{tabular}


Table 4 presents the effects of the earning discount of the region where university education was obtained, measured by a set of variables. For the analysis including all respondents, the results of the first model suggest that those who completed university in Asia and, unexpectedly, those who completed university in USA, UK, and Western Europe experienced foreign education earning discounts. The second model shows that social networks significantly increase the earnings of immigrants, and also reduce the earning discount. For those completing university in Asia, the earning discount becomes statistically insignificant, while for those completing university in US, UK, or Western Europe it is reduced.

The earning discount of the region where university education was received is insignificant for those who work in professional occupations. The results in the first model show that the region where the university education was received is statistically insignificant, except those who graduated from US, UK, and Western Europe universities. The insignificant relationship remains when the variables of social networks are included in the analysis. In nonprofessional occupations, there are earning discounts for immigrants who completed university in most of the regions. However, when the social networks of respondents are controlled, although the results still remain, the effects are considerably reduced.

Finally, we consider the earning discounts associated with the regions where foreign education was received together with the university rankings. For this analysis, we differentiate only "Asian," "US, UK, and Western European" universities by their rankings because we only have a small number of respondents who graduated from prestigious universities in Eastern Europe and other regions. As in the previous analysis, we included only those who completed their university education overseas, and ran separate analyses for those working in professional and nonprofessional occupations.

The first and second columns of Table 5 present the results for all respondents. The results show that not all graduates of Asian universities experienced earning discounts, only those who completed university in lowranking institutions. The results, surprisingly, also show that immigrants who graduated from high-ranking universities in the USA, UK, or Europe have lower earnings. The second column includes social networks. None of these earning discounts are statistically significant once the social networks are taken into consideration.

When only respondents working in professional occupations are considered, the rankings of foreign universities in different regions do not show any significant effect on earnings, except for those who graduated from lowranking universities in US, UK, and Western Europe. The results suggest 


\section{Table 5. Interval Regression Estimates of Earnings on Foreign Education from Universities with different Rankings by Region and other Selected Variables}

\begin{tabular}{|c|c|c|c|c|c|c|}
\hline & \multicolumn{2}{|c|}{ All } & \multicolumn{2}{|c|}{ Professional } & \multicolumn{2}{|c|}{ Nonprofessional } \\
\hline & Model 1 & Model 2 & Model 1 & Model 2 & Model 1 & Model 2 \\
\hline Asia, high ranking & -0.067 & 0.018 & 0.246 & 0.290 & -0.309 & -0.173 \\
\hline Asia, low ranking & $-0.272^{\star \star}$ & -0.202 & 0.047 & 0.070 & $-0.491^{\star \star}$ & $-0.390^{\star}$ \\
\hline $\begin{array}{l}\text { US, UK, Western Europe, high } \\
\text { ranking }\end{array}$ & $-0.546^{\star \star}$ & -0.388 & -0.442 & -0.258 & $-0.669^{\star}$ & -0.589 \\
\hline $\begin{array}{l}\text { US, UK, Western Europe, low } \\
\text { ranking }\end{array}$ & -0.491 & -0.487 & $-0.624^{*}$ & -0.591 & -0.365 & -0.386 \\
\hline Eastern Europe & -0.310 & -0.239 & -0.032 & 0.025 & $-0.474^{\star}$ & -0.401 \\
\hline Others & -0.250 & -0.215 & 0.086 & 0.084 & -0.309 & -0.249 \\
\hline Canada & $\mathrm{CC}$ & $\mathrm{CC}$ & $\mathrm{cc}$ & $\mathrm{CC}$ & $\mathrm{Cc}$ & $\mathrm{CC}$ \\
\hline \multicolumn{7}{|l|}{$\begin{array}{l}\text { Demographic and } \\
\text { socioeconomic factors }\end{array}$} \\
\hline Age & $0.021^{\star \star \star}$ & $0.019^{\star \star \star}$ & $0.027^{\star \star \star}$ & $0.026^{\star \star \star}$ & $0.018^{\star \star}$ & $0.016^{\star \star}$ \\
\hline Gender (female=1) & $-0.320^{\star \star \star}$ & $-0.337^{\star \star \star}$ & -0.132 & -0.153 & $-0.399^{\star \star \star}$ & $-0.409^{\star \star \star}$ \\
\hline Visible minority & -0.117 & -0.119 & 0.132 & 0.129 & $-0.295^{\star}$ & $-0.301^{*}$ \\
\hline $\begin{array}{l}\text { Language ability: well and very } \\
\text { well }\end{array}$ & $0.622^{\star \star \star}$ & $0.546^{\star \star \star}$ & $0.643^{\star}$ & 0.577 & $0.541^{\star \star}$ & $0.488^{\star}$ \\
\hline $\begin{array}{l}\text { Professional } \\
\text { occupations }\end{array}$ & $0.296^{\star \star \star}$ & $0.305^{\star \star \star}$ & & 0.154 & & \\
\hline Ln (weeks of work) & -0.030 & -0.036 & $0.169^{*}$ & $0.389^{*}$ & -0.163 & -0.158 \\
\hline Ln (hours of work) & 0.118 & $0.122^{\star}$ & $0.379^{*}$ & $0.158^{\star}$ & $0.241^{\star \star}$ & $0.233^{\star \star}$ \\
\hline Canadian born & 0.012 & -0.012 & 0.184 & 0.128 & -0.107 & -0.120 \\
\hline \multicolumn{7}{|l|}{ Social networks } \\
\hline Upper reachability & & $0.019^{*}$ & & 0.011 & & $0.027^{\star \star}$ \\
\hline Extensity & & 0.004 & & 0.004 & & 0.002 \\
\hline Intercept & $2.143^{\star \star \star}$ & 0.745 & 0.070 & -0.725 & $2.638^{\star \star \star}$ & 0.800 \\
\hline Sigma & 0.707 & 0.691 & 0.557 & 0.548 & 0.758 & 0.741 \\
\hline $\mathrm{N}$ & 452 & 452 & 172 & 172 & 280 & 280 \\
\hline Log likelihood & -721.14 & -711.71 & -285.51 & -282.88 & -410.24 & -404.28 \\
\hline
\end{tabular}

that whether the local employer is familiar with the educational system of the foreign region does not relate to earnings. All effects of foreign education become insignificant when the respondents' social networks are considered. In nonprofessional occupations, immigrants who graduated from low-ranking Asian universities and high-ranking US, UK, and European universities earn significantly less. When social networks are included, the earning discounts for low-ranking Asian universities are reduced. At the same time, the earning discounts for high-ranking US, UK, and western European universities become insignificant. 


\section{Conclusion}

The research reported here explores the effects of foreign education on earnings. Previously, most studies were based on indirect, estimated information about foreign education, and documented the lower earnings of immigrants who had foreign education in comparison to those who had domestic education. Using direct information obtained from respondents, this research goes beyond the existing studies by exploring the earning discounts of foreign education, consisting of (1) whether the highest level of education was received overseas; (2) the country where foreign education was received, and (3) local recognition of the foreign university.

Our results show that the discount on earnings is significant among immigrants who received their highest education in foreign countries. Furthermore, all those with foreign education have lower earnings, regardless of the university's ranking. The results suggest that it is not that local employers are unfamiliar with the foreign university, but the foreign university education itself that affects the earnings of immigrants. Our results confirm that the earning discount is found among those who completed university in Asia and, unexpectedly, those who completed university in US, UK, and Western Europe. It is possible that the indicator is too crude to reveal whether the name of foreign universities is recognizable by local employers. In short, the results clearly show that foreign education does not necessarily lead to discount in earnings. It depends on when and where the immigrants received the foreign education.

Our results also show that the foreign education effects on earnings differ between professional and nonprofessional occupations. The discount is virtually insignificant to the earnings of people working in professional occupations; it matters little whether the highest level of education was received overseas, from what country the foreign education was received, and if there is local recognition of the foreign university. The isomorphic pressure among professional occupations prevents sheepskin discount on earnings. However, both the country where foreign education was obtained and local recognition of the foreign university are strongly related to those working in nonprofessional occupations. Effect of country where foreign education was received is found among individuals who completed foreign university in most regions, and an interaction effect of the country where foreign university was received and ranking of the university is found among those who received university education in low-ranking Asian universities and high-ranking US, UK, and western European universities. Thus, in addition to when and where immigrants receive foreign education, whether they are in professional or nonprofessional occupations is also an 
important determinant of foreign education discount.

Finally, the findings clearly indicate the importance of social networks to alleviate the foreign education discount. In particular, our analysis shows that extensive social networks help to reduce the foreign education discount. For example, the negative effect on earnings of completing education in the top 500 foreign universities or in Asian universities becomes insignificant once the extensity of social networks is controlled. However, the effects of social networks on earnings are minimal among those who are in professional occupations. These findings echo the assertion that immigrants are actively using their resources to minimize institutional constraints as they integrate into the new society. However, their efforts can have limitations when facing strong institutional forces.

Our study has advanced the understanding of the effect of foreign education on earnings. The relationship revealed between foreign education and earnings is more complicated than discussed in previous studies. We have shown that the negative effects of foreign education on earnings depend on where and when the foreign education was received. The effects are also influenced by occupational type. Thus, any future discussion of the effects of foreign education on earnings should take these factors into consideration.

The findings have another message. Despite facing institutional constraints, immigrants are able to minimize the effects through their social networks. Thus, the study of the effects of foreign education is a classic example of the outcomes of the dual processes of the economic adaptation process of immigrants. The economic outcomes of immigrants are not just passively shaped by existing constraints; the active mobilization of resources by immigrants minimizes institutional constraints.

Nevertheless, the study raises questions that require further study. The earning discount related to the ranking appears to be more complicated. Specifically, there is a general discount effect for top-ranking foreign universities and the earning discount is also found among those who graduated from top-ranking universities in US, UK, and Western Europe. It is possible that the variable may be too crude to indicate whether the name of foreign universities is recognizable by local employers. Future studies should explore this particular group of immigrants. In addition, it is possible immigrants receive foreign education in a country different from their home country. Future studies could compare the effects of those who received foreign university education in their home country and those who received it elsewhere. Finally, future studies should also explore how differences in foreign education quality affect the discount effects (Sweetman, 2005).

The findings have significant policy implications. Policies should promote understanding and provide information about foreign education, espe- 
cially about countries with systems not familiar to local employers. Clear guidelines and procedures should be developed to help employers evaluate applicants with foreign education for nonprofessional occupations. In addition, policies should facilitate the development of networks among immigrants, as our study has indicated that immigrants actively alleviate their earnings discount through their networks.

Given that the effects of foreign education on earnings reflect the institutional constraints of the immigrant adaptation process, the findings reported here can be country-specific. It is quite possible that immigrants educated in foreign countries could be well received in other countries. Thus, the findings should not be generalized to other countries. However, the study does point out the complexity of the effects of foreign education on earnings in North America.

\section{References}

Alba, Richard and Victor Nee. 1997. "Rethinking assimilation theory for a new era of immigration." International Migration Review 31:826-874.

2003. Remaking the American Mainstream: Assimilation and Contemporary Immigration. Cambridge, MA: Harvard University Press.

Aydemir, Abdurrahmann and Mikal Skuterud. 2005. "Explaining the deteriorating entry earnings of Canada's immigrant cohorts, 1996-2000." Canadian Journal of Economics 38:641-672.

Baker, Michael and Dwayne Benjamin. 1995. "The performance of immigrants in the Canadian labor market.” Journal of Labor Economics 12:369-465.

Barringer, H.R., D.T. Takeuchi, and P. Xenos. 1990. "Education, occupational prestige, and income of Asian Americans." Sociology of Education 63:27-43.

Barth, Fredrik. 1969. Ethnic Groups and Boundaries: The Social Organization of Culture Difference. Boston: Little, Brown.

Behrman, Jere R., Mark R. Rosenzweig, and Paul Taubman. 1996. "College choice and wages: Estimates using data on female twins.” The Review of Economics and Statistics 78:672 685 .

Belman, Dale and John S. Heywood. 1991. "Sheepskin effects in the returns to education: An examination of women and minorities." Review of Economics and Statistics 73:720-724.

Borjas, George. 1982. "The earnings of male Hispanic immigrants in the United States." Industrial and Labor Relations Review 35:343-353.

Boyd, Monica. 2001. “Asian immigrant engineers in Canada.” in W.A. Cornelius, T.J. Espenshade, and I. Salehyan, eds., The International Migration of the Highly Skilled: Demand, Supply, and Development Consequences in Sending and Receiving Countries. San Diego: Centre for Comparative Immigration Studies, University of California, San Diego. 
Bratsberg, B. and D. Terrell. 2002. "School quality and returns to education of U.S. immigrants.” Economic Inquiry 40:177-198.

Card, David and Alan Krueger. 1992a. "Does school quality matter: Returns to education and the characteristics of public schools in the United States." Journal of Political Economy 100:1-40.

-1992b. "School quality and black-white relative earnings: A direct assessment." Quality Journal of Economics 107:151-200.

DaVanzo, Julie S. and Peter A. Morrison. 1981. "Return and other sequences of migration in the United States." Demography 18:85-101.

Dimaggio, Paul J. and Walter W. Powell. 1983. "The iron cage revisited: Institutional isomorphism and collective rationality in organizational fields." American Sociological Review 48:147-160.

Fernandez, Roberto M. and Isabel Fernandez-Mateo. 2006. "Networks, race, and hiring." American Sociological Review 71:42-71.

Ferrer, Ann M. and W. Craig Riddell. 2002. "The role of credentials in the Canadian labour market." Canadian Journal of Economics 35:879-905.

Fligstein, Neil. 2001. The Architecture of Markets: An Economic Sociology of Capitalist Societies. Princeton, NJ: Princeton University Press.

Ganzeboom, Harry B.G. and Donald J. Treiman. 1996. "Internationally comparable measures of occupational status for the 1988 international standard classification of occupations." Social Science Research 25:201-239.

Heckman, James, Anne Layne-Farra, and Petra Todd. 1996. "Human capital pricing equations with an application to estimating the effect of schooling quality on earnings." The Review of Economics and Statistics 78:562-610.

Jaeger, David A. and Marianne E. Page. 1996. "Degrees matter: New evidence on sheepskin effects in the returns to education." The Review of Economics and Statistics 78:733-740.

Kennedy, Bonnie. 2003. "A spring 2003 snapshot: The current status of prior learning assessment and recognition (PLAR) in Canada's public postsecondary institutions: Part one." P. 80: Council of Ministers of Education, Canada.

Krupka, Douglas J. 2004. "Location-specific human capital, migration and amenities." Atlanta, GA: Georgia State University.

Leicht, Kevin T. and Mary L. Fennell. 2001. Professional Work: A Sociological Approach. Malden, MA: Blackwell Publishers, Inc.

Li, Peter S. 2001. "The market worth of immigrants' educational credentials." Canadian Public Policy 27:23-38.

Light, Ivan and Steven Gold. 2000. Ethnic Economies. San Diego: Academic Press.

Lin, Nan. 2001. Social Capital: A Theory of Social Structure and Action New York: Cambridge University Press.

Lin, Nan and Mary Dumin. 1986. "Access to occupations through social ties.” Social Networks 8:365-385. 
Lofstrom, Margnus. 2001. "Self-employment and earnings among high-skilled immigrants in the United States." In W.A. Cornelius, T.J. Espenshade, and I. Salehyan, eds., The International Migration of the Highly Skilled: Demand, Supply, and Development Consequences in Sending and Receiving Countries San Diego: Center for Comparative Immigration Studies, University of California, San Diego.

Nee, Victor and Paul Ingram. 1998. "Embeddedness and beyond: Institutions, exchange, and social structure.” Pp. 19-45 in V. Nee and M. Brinton, eds., The New Institutionalism in Sociology. New York: Russell Sage Foundation.

Ooka, Emi and Barry Wellman. 2006. "Does social capital pay off more within or between ethnic groups? Analyzing job searchers in five Toronto ethnic groups.” Pp. 199-226 in E. Fong, ed., Inside the Mosaic. Toronto: University of Toronto Press.

Park, Jin Heum. 1999. "Estimation of sheepskin effects using the old and the new measures of educational attainment in the Current Population Survey." Economic Letters 62:237240 .

Reitz, Jeffrey G. 1999. Warmth of the Welcome: The Social Causes of Economic Success for Immigrants in Different Nations and Cities Boulder, CO: Westview Press

Sanders, Jimy. 2002. "Ethnic boundaries and identity in plural societies." Annual Review of Sociology 28:327-357.

Sanders, Jimy and Victor Nee. 1987. "Limits of ethnic solidarity in the enclave economy." American Sociological Review 52:745-767.

Sanders, Jimy, Victor Nee, and Scott Sernau. 2002. “Asian immigrants' reliance on social ties in a multiethnic labor market.” Social Forces 81:281-314.

Shibutani, Tamotsu and Kian M. Kwan. 1965. Ethnic Stratification. New York: Macmillan.

Smith, Sandra Susan. 2005. “'Don’t put my name on it': Social capital activation and job-finding assistance among the Black urban poor.” American Journal of Sociology 111:1-57.

Sweetman, Arthur. 2005. "Immigration as a labour market strategy: Canada." Brussels, Belgium: Migration Policy Group.

Tang, Joyce. 1993. "The career attainment of Caucasian and Asian engineers." Sociological Quarterly 34:467-496.

Waldinger, Roger. 1999. "Network, bureaucracy, exclusion: Recruitment and selection in an immigrant metropolis."'In F. Bean and S. Bell-Rose, eds., Immigration and Opportunity: Race, Ethnicity, and Employment in the United States. New York: Russell Sage Foundation.

Waldinger, Roger, Howard Aldrich, and Robin Ward. 1990. Ethnic Entrepreneurs: Immigrant Business in Industrial Societies. Newbury Park, CA: Sage Publications.

Zeng, Zhen and Yu Xie. 2004. “Asian-Americans' earnings disadvantage reexamined: The role of place of education.” American Journal of Sociology 5:1075-1108. 
Appendix 1. Descriptive Statistics of Independent Variables (All Respondents, $\mathrm{N}=1087$ )

\begin{tabular}{lrrrr}
\hline \hline & Mean & Standard deviation & Minimum & Maximum \\
\cline { 2 - 5 } Age & 39.69 & 12.84 & 18 & 65 \\
Gender (Female=1) & 0.63 & 0.48 & 0 & 1 \\
Visible minority & 0.42 & 0.49 & 0 & 1 \\
Language ability, well and & 0.70 & 0.20 & 0 & 1 \\
very well & 0.30 & 0.46 & 0 & 1 \\
Professional occupations & 43.89 & 15.33 & 0 & 52 \\
Weeks of work & 37.24 & 12.78 & 0 & 120 \\
Hours of work & 0.39 & 0.49 & 0 & 1 \\
Canadian born & & & & \\
Social networks & 69.59 & 6.76 & 21 & 73 \\
Upper reachability & 39.88 & 14.05 & 0 & 52 \\
Extensity & & \\
n=1245 & Note: work months and hours are only available for working respondents. \\
\hline
\end{tabular}


